\title{
PELATIHAN PEMBUATAN ABON IKAN TONGKOL UNTUK MENINGKATKAN PENDAPATAN MASYARAKAT PESISIR DI DESA SERAYA TIMUR KABUPATEN KARANGASEM
}

\author{
I.K.W. Negara ${ }^{1}$, P.G.S. Julyantoro ${ }^{2}$, E.W. Suryaningtyas ${ }^{3}$, D.A.A. Pebriani ${ }^{4}$, N.P.P. Wijayanti ${ }^{5}$, \\ S.A. Saraswati ${ }^{6}$
}

\begin{abstract}
ABSTRAK
Besarnya hasil tangkapan ikan tongkol di Kabupaten Karangasem, sehingga aktivitas perdagangannya juga semakin berkembang sangat pesat. Ikan tongkol juga memberikan dampak ekonomi terhadap setiap kegiatan usaha perikanan di wilayah tersebut. Pelaksanaan program dilaksanakan di Desa Seraya Timur, Kabupaten Karangasem dan dimulai dari; Tahapan Persiapan, Tahap Pelaksanaan, Tahap Evaluasi. Komposisi bahan bumbu untuk daging abon tongkol 3 kg adalah sebagai berikut; Kunyit 60 gr, Jahe 60 gr, Lengkuas 60 gr, Ketumbar (halus) 1 sendok makan, Garam 9 sendok makan, Cabe Merah Besar 6 Biji, Cabe Merah 15 Biji, Bawang Putih 75 gr, Bawang Merah 75 gr, Gula Pasir 6 Sendok Makan, Gula Merah 10 gr, Daun Salam 12 lembar, Sereh 3 Batang, Daun Jeruk 12 lembar, Santan 1.200 ml, Minyak Goreng 6 Sendok Makan dan Santan $1.200 \mathrm{ml}$. Pentingnya proses pengemasan yang tepat juga dapat meningkatkan daya tarik konsumen dan memiliki nilai jual yang lebih tinggi
\end{abstract}

Kata Kunci : Pengolahan, Abon, Tongkol, Diversifikasi, Seraya Timur

\begin{abstract}
The implementation program was held in Seraya Timur Village, Karangasem Regency and started from; Stages of Preparation, Implementation Phase, Evaluation Phase. compose by three steps. The first is preparation then processing and the last steps is evaluation. The result of this workshop is the increased of enthusiasm in East Seraya Village to adopt this new information by making Abon Mackerel Tuna. The ingredients of spices for $3 \mathrm{~kg}$ of Abon Mackerel Tuna as follows; 60 gram of turmeric, 60 grams of jahe, 60 grams of galangal, 1 tablespoon of coriander (smooth), 9 tablespoons of salt, 6 seeds of large red chillies, 15 seeds of red chili, 75 gr of garlic, 75 grams of red onion, 6 spoons of sugar, 10 grams of brown sugar, 12 pieces of salam leaf, 3 sticks of lemongrass, 12 pieces of orange leaves, 1,200 ml of frying milk, 6 tablespoons of cooking oil, and 1,200 $\mathrm{ml}$ of coconut milk. Abon that has been packaged properly can increase the sale value and attractiveness of consumers to the abon product. In addition, selling value and

\footnotetext{
${ }^{1}$ Staf Pengajar Jurusan Manajemen Sumberdaya Perairan Fakultas Kelautan dan Perikanan Universitas Udayana, wijanegara@unud.ac.id

${ }^{2}$ Staf Pengajar Jurusan Manajemen Sumberdaya Perairan Fakultas Kelautan dan Perikanan Universitas Udayana

${ }^{3}$ Staf Pengajar Jurusan Manajemen Sumberdaya Perairan Fakultas Kelautan dan Perikanan Universitas Udayana

${ }^{4}$ Staf Pengajar Jurusan Manajemen Sumberdaya Perairan Fakultas Kelautan dan Perikanan Universitas Udayana

${ }^{5}$ Staf Pengajar Jurusan Manajemen Sumberdaya Perairan Fakultas Kelautan dan Perikanan Universitas Udayana

${ }^{6}$ Staf Pengajar Jurusan Manajemen Sumberdaya Perairan Fakultas Kelautan dan Perikanan Universitas Udayana
} 
additional income, this abon product can also be promoted as a typical food in East Seraya Village

Keywords: Processing, Abon, Mackerel Tuna, Diversification, Seraya Timur

\section{PENDAHULUAN}

Alur perdagangan hasil tangkapan ikan di Kabupaten Karangasem sangat bervariasi digolongkan menurut hasil tangkapan ikan tang diperdagangkan. Salah satu komoditas ikan yang memiliki nilai ekonomis dan memberikan dampak ekonomi terhadap masyarakat pesisir di Kabupaten Karangasem adalah komoditas ikan tongkol. Total produksi hasil tangkapan ikan di Kabupaten Karangasem tahun 2015 adalah sebanyak 24.907,18 ton/tahun. Dengan hasil tangkapan paling dominan yaitu ikan tongkol sebesar 20.278,10 ton pada tahun 2015 atau $81 \%$ dari total produksi perikanan di Kabupaten Karangasem (BPS, 2016).

Hasil tangkapan ikan tongkol di Kabupaten Karangasem, sehingga aktivitas perdagangannya juga semakin berkembang sangat pesat. Ikan tongkol juga memberikan dampak ekonomi terhadap setiap kegiatan usaha perikanan di wilayah tersebut. Selain ikan tongkol, di Kabupaten Karangasem juga memiliki potensi perikanan tangkap seperti; Cakalang, Tuna, Kakap, Kerapu, Kurisi dan ikan laiinya, potensi tersebut belum dieksplorasi secara maksimal dengan menggunakan alat tangkap yang tepat dan ramah lingkungan.

Ikan merupakan salah satu sumber protein hewani yang banyak dikonsumsi oleh masyarakat, mudah didapat dengan harga yang murah. Ikan mempunyai nilai protein yang tinggi dan kandungan lemaknya rendah, sehingga banyak memberikan tambahan kesehatan bagi tubuh manusia. Abon ikan merupakan jenis makanan yang terbuat dari ikan yang diberi bumbu dan diolah secara modern.

Menutrut Ismail dan Putra (2017), Inovasi produk dibutuhkan untuk meningkatkan kualitas dan difersiasi produk sehingga produk tersebut memiliki daya saing yang baik, peningkatn mutu dan efisiensi produk. Salah satunya pembuatan abon ikan bertujuan untuk mengolah ikan tanpa mengurangi nilai protein yang terdapat pada ikan dan meningkatkan nilai jual hasil tangkapannya dan memiliki skill baru dalam mengolah ikan tongkol sehingga dapat dijadikan sebagai modal dalam berwirausaha.

\section{METODE PELAKSANAAN}

Metode disusun secara sistematis sehingga program dapat terlaksana dengan baik. Untuk itu metode pelaksanaan program dimulai dari; Tahapan Persiapan, Tahap Pelaksanaan, Tahap Evaluasi. Tahap persiapan meliputi survey lokasi pengabdian di Desa Seraya Timur, Kecamatan 
Abang, Kabupaten Karangasem. Survey dilakukan untuk mengetahui jenis kondisi masyarakat di Desa Seraya Timur. Pengadaan bahan Baku. Bahan baku yang digunakan yaitu ikan tongkol hasil tangkapan nelayan di Desa Seraya Timur. Penyiapan alat dan bahan usaha yang di dalamnya mencakup resep pembuatan produk yang di buat. Penyiapan mitra usaha yaitu kelompok nelayan di Desa Seraya Timur.

Tahap pelaksanaan dilakukan dengan memberikan pelatihan pembuatan abon tongkol pada masyarakat Desa Seraya Timur. Pelatihan diberikan kepada para istri nelayan yang berjumlah 15 orang (ibu rumah tangga/keluarga nelayan), 10 Mahasiswa dan 6 Staf Pengajar Program Studi Manajemen Sumberdaya Perairan Fakultas Kelautan dan Perikanan Universitas Udayana. Pembuatan produk makanan berbahan baku tongkol yang dibuat mengacu pada resep yang telah ditetapkan dengan beberapa ulangan sehingga mendapatkan komposisi bahan yang dapat menjadikan abon tongkol sesuai dengan selera masyarakat di Nusantara.

Tahap evaluasi dilakukan untuk mengetahui perkembangan kemandirian masyarakat dari kegiatan pelatihan yang dilakukan. Melalui pelatihan tersebut diharapkan masyarakat mampu memiliki keterampilan dalam pengolahan produk perikanan yang mampu meningkatkan kesejahteraan dan kemandirian masyarakat di Desa Seraya Timur.

\section{HASIL DAN PEMBAHASAN}

Pembuatan abon tongkol menggunakan acuan perhitungan $5 \mathrm{~kg}$ ikan tongkol menghasilkan $3 \mathrm{~kg}$ daging yang siap untuk diolah menjadi abon. Sebelum mendapatkan daging dengan komposisi tersebut, ikan tongkol sebelumnya harus di kukus untuk mencegah terbentuknya histamine yang menyebabkan alergi atau keracunan (Indiati, $d k k$ 2006).

Komposisi bahan bumbu untuk daging tongkol $3 \mathrm{~kg}$ adalah sebagai berikut; Kunyit 60 gr, Jahe 60 gr, Lengkuas 60 gr, Ketumbar (halus) 1 sendok makan, Garam 9 sendok makan, Cabe Merah Besar 6 Biji, Cabe Merah 15 Biji, Bawang Putih 75 gr, Bawang Merah 75 gr, Gula Pasir 6 Sendok Makan, Gula Merah 10 gr, Daun Salam 12 lembar, Sereh 3 Batang, Daun Jeruk 12 lembar, Santan 1.200 ml, Minyak Goreng 6 Sendok Makan dan Santan 1.200 ml.

Abon dikemas siap untuk dipasarkan, pengemasan abon agar dapat nilai jual yang tinggi dapat menggunakan berbagai media kemas, salah satunya adalah menggunakan toples mini. Kegiatan ini memberikan pengetahuan kepada ibu-ibu rumah tangga di Desa Seraya Timur, Kecamatan Karangasem agar dapat meningkatkan nilai jual harga ikan tongkol. Tinggi rendahnya 
pendapatan akan sangat dipengaruhi oleh besar kecilnya produksi yang dicapai. Jumlah pendapatan atau laba sangat tergantung pada jumlah penerimaan dan besarnya biaya yang dikeluarkan dalam proses produksi (Syafar dan Lamusa, 2015).

Kegiatan Pengabdian Pelatihan Pembuatan Abon Ikan Tongkol Untuk Meningkatkan Pendapatan Masyarakat Pesisir Di Desa Seraya Timur, Kabupaten Karangasem ini diharapkan dapat memberikan motivasi dan pengetahuan kepada ibu-ibu istri nelayan, agar dapat memaksimalkan hasil tangkapan ikan di desa tersebut. Abon yang sudah terkemas dengan baik dapat meningkatkan nilai jual dan daya tarik konsumen terhadap produk abon tersebut. Selain nilai jual dan tambahan pengasilan, abon ini juga dapat dipromosikan sebagai makanan khas di Desa Seraya Timur.

\section{KESIMPULAN DAN SARAN}

\subsection{Kesimpulan}

Komposisi bahan bumbu untuk daging abon tongkol $3 \mathrm{~kg}$ adalah sebagai berikut; Kunyit 60 gr, Jahe 60 gr, Lengkuas 60 gr, Ketumbar (halus) 1 sendok makan, Garam 9 sendok makan, Cabe Merah Besar 6 Biji, Cabe Merah 15 Biji, Bawang Putih 75 gr, Bawang Merah 75 gr, Gula Pasir 6 Sendok Makan, Gula Merah 10 gr, Daun Salam 12 lembar, Sereh 3 Batang, Daun Jeruk 12 lembar, Santan 1.200 ml, Minyak Goreng 6 Sendok Makan dan Santan 1.200 ml. Pengemasan produk dapat menarik minat konsumen dan menjaga hasil produksi agar tahan lama.

\subsection{Saran}

Hasil tangkapan ikan tongkol di Desa Seraya Timur sangat bergantung musim, sehingga perlu dilakukan banyak divesifikasi hasil tangkapan lainnya seperti tongkol asap, tongkol balado dan produk olahan lainnya, agar saat musim panen ikan tongkol harga jual dapat terkendali

\section{UCAPAN TERIMAKASIH}

Penulis menyampaikan terima kasih yang sebesar-besarnya kepada Direktorat Riset dan Pengabdian Kepada Masyarakat Direktorat Jenderal Penguatan dan Pengembangan Kementerian Riset, Teknologi dan Pendidikan Tinggi sehigga pengabdian ini dapat terlaksana, Ketua Lembaga Pengabdian kepada Masyarakat Universitas Udayana, serta seluruh masyarakat Desa Seraya Timur yang telah membantu kelancaran kegiatan ini. 


\section{DAFTAR PUSTAKA}

BPS. 2016. Kabupaten Karangasem Dalam Angka 2016. Badan Pusat Statistik. Kabupaten Karangasem

Indiati, N., Rispeyeni., Heruwati, E.S. (2006). Studi Bakteri Pembentuk Histamin Pada Ikan Kembung Peda Selama Proses Pengolahan. Jurnal Pascapanen dan Bioteknologi Kelautan dan Perikanan. Vol. 1 (2) : 117 - 123

Ismail, A.M dan Putra, D.E. 2017. Inovasi Pembuatan Abon Ikan Cakalang Dengan Penambahan Jantung Pisang. AGRITECH : Vol. 19 (1) : 45-54

Syafar, M.N dan Lamusa, A. 2015. Analisis Pendapatan Usaha Abon Ikan Tenggiri Pada Industri Rumah Tangga “Althaf Food” di Kota Palu. E-Jurnal Agrotekbis 3 (2) : 255 - 260.
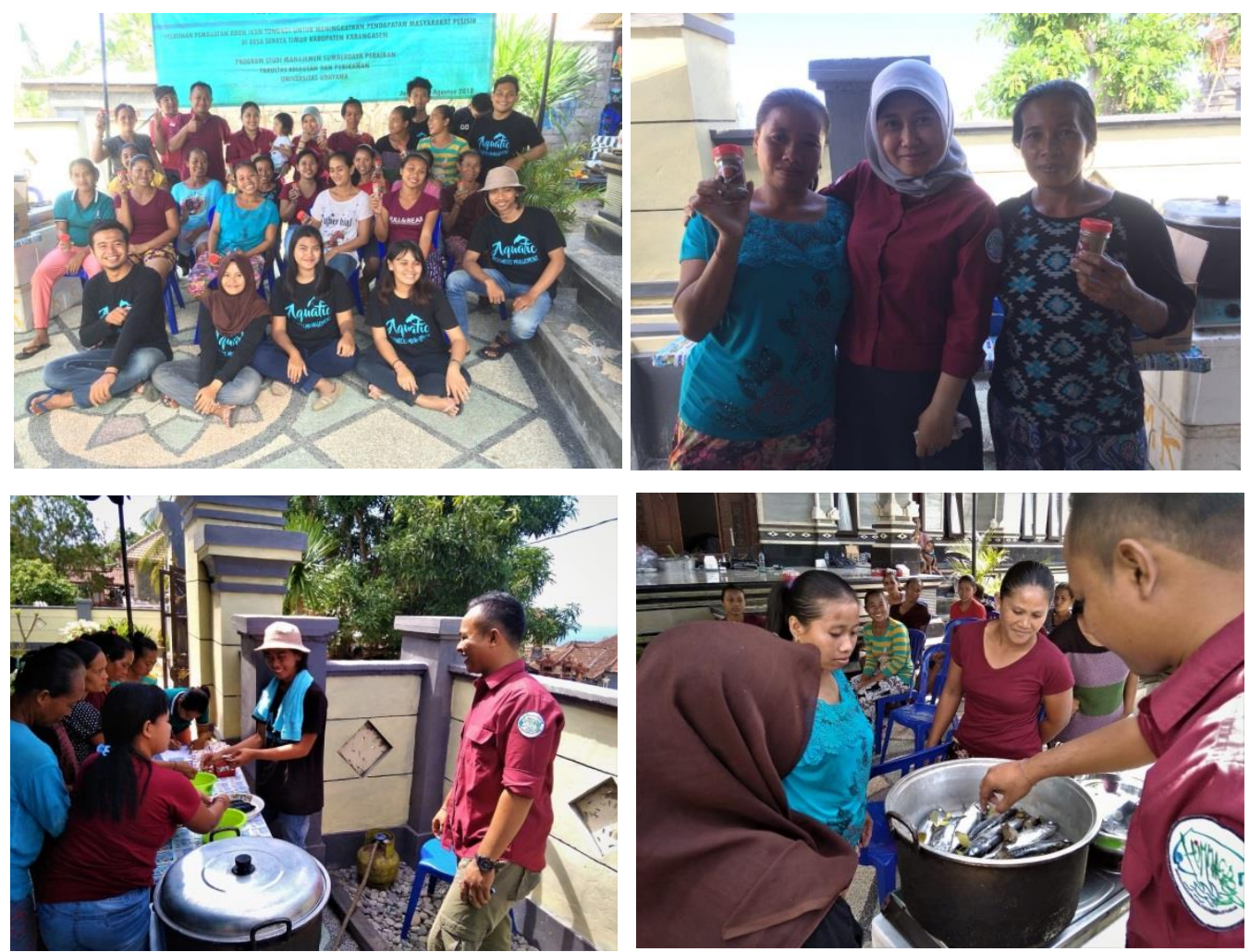

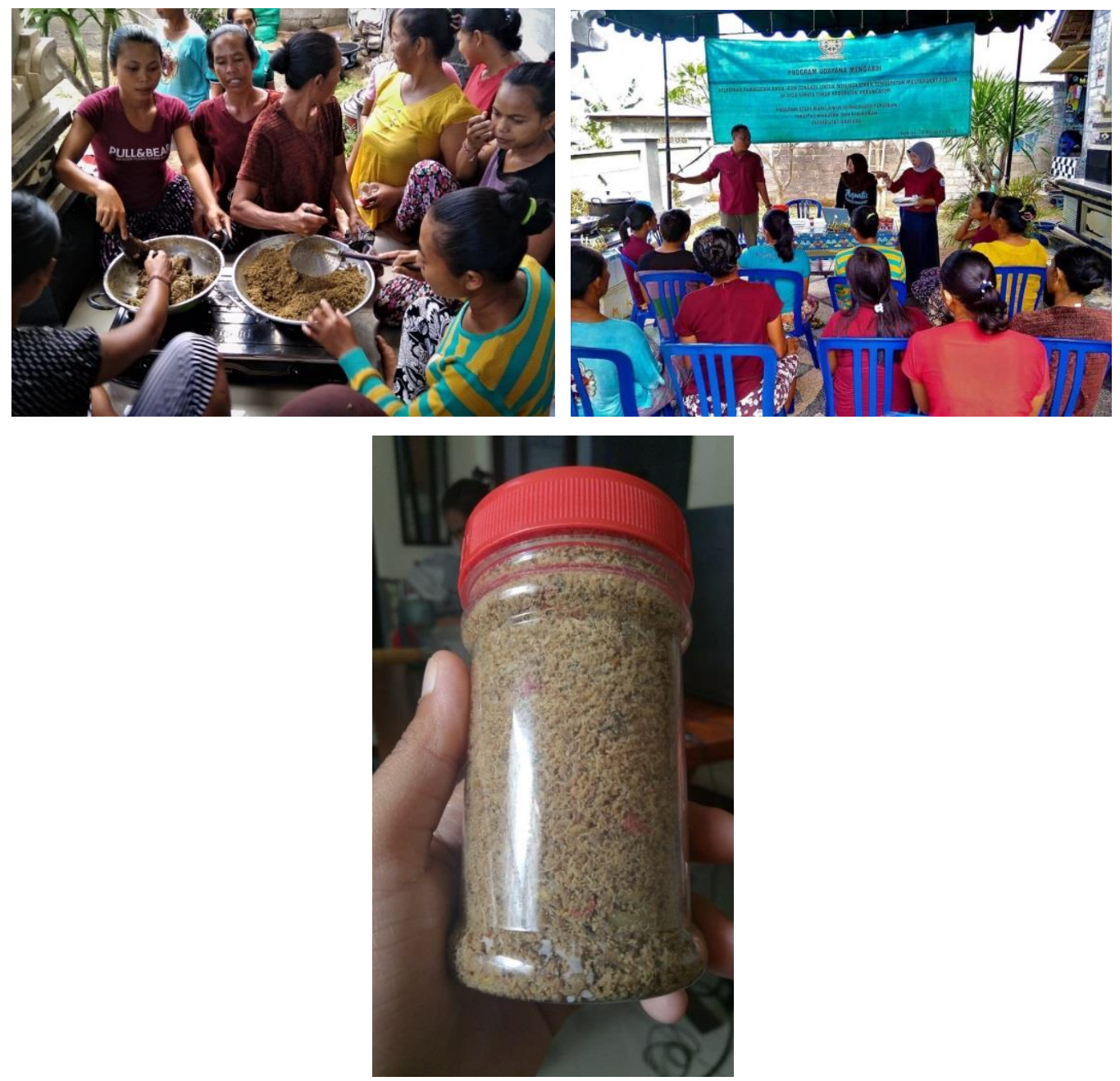